\title{
OBESITY IN AGED HYPERTENSION PATIENTS
}

\author{
Maria Alice Rodrigues Mártires ${ }^{1}$, Maria Arminda Mendes Costa², Célia Samarina Vilaça Santos ${ }^{3}$
}

${ }^{1}$ Doctoral student in Nursing at Universidade de Lisboa. Faculty, Coordinator, Escola Superior de Enfermagem de Vila Real, Universidade de Trás-os-Montes e Alto Douro. Vila Real, Portugal. E-mail: mmartires@utad.pt

${ }^{2}$ Ph.D. in Educational Sciences. Faculty at Escola Superior de Enfermagem do Porto (ESEP). Researcher, Research and Training Unit, Instituto de Ciências Biomédicas Abel Salazar da Universidade do Porto. Porto, Portugal. E-mail: arminda@esenf.pt

${ }^{3}$ Ph.D. in Health Psychology, Faculty at ESEP. Porto, Portugal. E-mail: celiasantos@esenf.pt

ABSTRACT: Exploratory and descriptive study with a quantitative approach, performed in a Health Centre in Portugal, whose goals were to characterize older adults with hypertension and identify cardiovascular risk factors associated with systemic arterial hypertension. The sample consisted of 250 older adults who, in a free and enlightened way, agreed to answer a structured interview. From the older adults surveyed, $43.6 \%$ were overweight and $39.6 \%$ were obese. It should be noted that $69.6 \%$ of the older adults had blood pressure over $140 / 90 \mathrm{mmHg}$ and $50.4 \%$ had total cholesterol $\geq 200 \mathrm{mg} / \mathrm{dl}$. In conclusion, the majority of the older adult respondents had uncontrolled blood pressure levels as well as other cardiovascular risk factors, which highlights the importance of self-care in the control of chronic hypertension and better access to quality nursing care to promote healthier aging.

DESCRIPTORS: Aged. Hypertension. Obesity. Nursing.

\section{OBESIDADE EM IDOSOS COM HIPERTENSÃO ARTERIAL SISTÉMICA}

RESUMO: Estudo exploratório e descritivo, com abordagem quantitativa, realizado num Centro de Saúde em Portugal, cujos objetivos foram caraterizar idosos hipertensos em tratamento ambulatorial e identificar fatores de risco cardiovascular associados à hipertensão arterial sistémica. A amostra foi constituída por 250 idosos que aceitaram responder a um inquérito estruturado. Dos idosos questionados, $43,6 \%$ apresentavam sobrepeso e $39,6 \%$ obesidade. Cabe salientar que $69,6 \%$ apresentavam valores de pressão arterial $\geq 140 / 90 \mathrm{mmHg}$ e $50,4 \%$ apresentavam valores de colesterol total $\geq 200 \mathrm{mg} / \mathrm{dl}$. Conclui-se, portanto, que a maioria dos idosos não apresentava valores da pressão arterial controlados, assim como de outros fatores de risco cardiovascular, destacando a importância das intervenções de enfermagem às pessoas idosas e família, de forma a encorajar e fazer interagir, a responsabilidade pessoal no autocuidado para o controle da doença crônica, e o acesso a cuidados de enfermagem de qualidade, com vista à promoção de um envelhecimento mais saudável.

DESCRITORES: Idosos. Hipertensão. Obesidade. Enfermagem.

\section{OBESIDAD EN ANCIANOS CON HIPERTENSIÓN}

RESUMEN: Estudio exploratorio, descriptivo y cuantitativo, realizado en un Centro de Salud en Portugal, cuyos objetivos fueron caracterizar ancianos hipertensos en tratamiento ambulatorio e identificar factores de riesgo cardiovascular asociados a la hipertensión arterial sistémica. La muestra fue constituida por 250 ancianos que aceptaran contestar a un cuestionario estructurado. De los ancianos encuestados, $43,6 \%$ presentaban sobrepeso y $39,6 \%$ obesidad. Hay que señalar que $69,6 \%$ de los ancianos presentaban valores de presión arterial $\geq 140 / 90 \mathrm{mmHg}$ y $50,4 \%$ presentaban colesterol total $\geq 200 \mathrm{mg} / \mathrm{dl}$. Se concluye que la mayoría de los ancianos no estaban controlados los valores de la presión arterial, así como otros factores de riesgo cardiovascular, destacando la importancia de intervenciones de Enfermería a los ancianos y familiares de forma a encorajar la responsabilidad personal en auto-cuidado para el control de enfermedad crónica y el acceso a los cuidados de Enfermería de calidad con vista a la promoción de un envejecimiento saludable.

DESCRIPTORES: Ancianos. Hipertensión. Obesidad. Enfermería. 


\section{INTRODUCTION}

The World Health Organization (WHO) defines obesity as a disease in which excessive body fat accumulation presents a risk to health. ${ }^{1}$ The most widely accepted definition related to the increased quantity of body fat. This increase results in body weight due to fat tissue. ${ }^{1}$

Obesity can be diagnosed through different parameters. Around the world, the most used one is the Body Mass Index (BMI), defined as: BMI = weight $(\mathrm{kg}) /$ height $\left(\mathrm{m}^{2}\right)$. Obesity can be classified in different levels with a view to a more precise diagnosis: ${ }^{2}$ underweight $<18.5 \mathrm{Kg} / \mathrm{m}^{2}$; normal weight or normal variation $\geq 18.5-24.9 \mathrm{Kg} / \mathrm{m}^{2}$; overweight or pre-obesity $\geq 25.0-29.9 \mathrm{Kg} / \mathrm{m}^{2}$; level I obesity $\geq 30.0-34.9 \mathrm{Kg} / \mathrm{m}^{2}$; level II obesity $\geq 35-39.9 \mathrm{Kg} / \mathrm{m}^{2}$; and level III or morbid obesity $\geq 40 \mathrm{Kg} / \mathrm{m}^{2}$.

The prevalence of overweight and obesity in the Portuguese adult population has been assessed through the BMI, with a mean prevalence of about $34 \%$ for overweight and $12 \%$ for obesity. ${ }^{3}$

There are different causes of obesity: ${ }^{1}$ genetic causes, in families with different obese persons and in which the genetic factor can be enhanced by bad living habits: excessive calorie intake, in which the excessive consumption of caloric foods is accumulated in the organism in the form of triglycerides, increasing the fat cells; endocrine alterations like hypothyroidism, Cushing's Syndrome and hypophyseal alterations, which affect about $5 \%$ of obese people; emotional alterations, in compensation or satisfaction; medication interaction, associated with weight gain in some drugs, like tricyclic antidepressants; physiological alterations related to aging in men and women, with weight gain during the female menopause due to lack of estrogen; sociocultural and economic factors, with the lower social classes consuming foods with higher sugar and fat contents, due to their lower price, besides bad eating habits and decreased physical exercise.

Various illnesses are associated with obesity, such as Systemic Arterial Hypertension (SAH) and other cardiovascular illnesses, dislipidemias, type II Diabetes Mellitus, hepatobiliary alterations, sleep apnea, risk of post-surgical complications with bad tissue healing, infections and psychological problems with emotional alterations. The predominance of diabetes and SAH almost triples in people with more than $20 \%$ of overweight. Epidemiological studies demonstrate that obesity is the main predisposing cause of SAH and type II Diabetes Mellitus. Obesity can be endogenous, when related to hypothyroidism, Cushing's Disease, or exogenous, when related to lifestyle, particularly diet. This represents about 90 to $95 \%$ of obesity cases. ${ }^{3}$

Fat distribution is not uniform. Android, abdominal or visceral obesity has been identified, when fat is mainly accumulated in the abdominal region. This is more frequent in adult and elderly men. Characteristic of this obesity is the excessive consumption of calorie-rich foods with metabolic consequences and complications, including type II Diabetes Mellitus, hyperuricemia, dislipidemia, arteriosclerosis, which are coronary risk factors. Gynoid obesity is primarily present in women with ovarian activity, when fat is mainly distributed in the gluteal-femoral region. Associated risk factors are varicose veins and arteriosclerosis. ${ }^{3}$

\section{Overweight, obesity and blood pressure in the aged}

About $50 \%$ of people aged 65 years or older with overweight and obesity suffer from $\mathrm{SAH}$, which means that many hypertensive elderly patients suffer from excess body weight. ${ }^{4}$ In one study, 60 to $70 \%$ of hypertensive patients attributed their increased Blood Pressure (BP) to their overweight and, in another, a relation is found between BMI and blood pressure. ${ }^{5}$ According to the authors, in most cases, dietary habits, through excessive calorie and salt intake, including the corresponding fluid retention, provoke increased body weight and blood pressure. Sedentariness and decreased physical exercise further aggravate this situation.

By itself, obesity represents a risk factor for cardiovascular diseases, like SAH, which is why both enhance the emergence of cardiac conditions. Overweight people suffer from increased cardiac debit, blood volume and more rigid blood vessel walls, giving room to SAH. ${ }^{5}$ One of the agents responsible for these alterations is the higher insulin secretion in response to the frequently high blood sugar levels. This excessive insulin leads to the thickening of blood vessels, increased cardiac debit, favoring the reabsorption of salt and water 
by the kidneys. In addition, the fat cells accumulated around the waist constitute fat reserves and act as messengers of the central nervous system, sending messages that are not always appropriate, deregulating satiation and insulin-related mechanisma. $^{5}$

Nurses know that elderly people's needs go beyond the physio-pathological alterations the chronic condition SAH provokes. Most patients experience difficulties related to the management of the therapeutic regimen, frequently leading to failure to control the SAH, causing further health complications and a worse quality of life. Nurses are competent in community health and occupy a privileged position in the promotion of healthcare and readaptation to chronic disease situations, which can contribute to reduce the number of hospitalizations and drug consumption, including the whole range of resulting consequences. ${ }^{6}$

This research was aimed at characterizing elderly hypertensive patients under outpatient treatment at a Health Center in Northern Portugal and at identifying risk factors for cardiovascular disease associated with SAH.

\section{METHOD}

A quantitative, exploratory, descriptive and cross-sectional research was undertaken at a Health Center in Northern Portugal between March 2010 and March 2011.

Participants were 250 elderly enrolled for regular SAH outpatient consultations. The following inclusion criteria were established: being 65years or older; being enrolled for arterial hypertension consultations at that Health Center; under outpatient treatment and taking anti-hypertensive medication; and not institutionalized. All patients accepted to participate in the study by signing the Informed Consent Form.

A structured survey was used for data collection, built for that purpose, addressing a set of questions to collect the elderly patients' social and demographic characteristics, assess different clinical parameters (systolic and diastolic BP, body weight, height, BMI, total cholesterol and HDL), as well as a set of questions about SAHrelated risk factors, such as daily activity, physical exercise, eating habits, alcohol, tobacco, leisure, sleep and prescribed drugs. Other data collection instruments were the Graffar scale to determine the social and economic level and the Measure of Treatment Adherence (MTA).

After authorization had been obtained from the Portuguese Health Sub-Region - ARS North, under protocol 14/2009, the instruments were applied. The objectives were explained and the elderly patients' cooperation was requested, guaranteeing their anonymity and confidentiality.

The database of the software Statistical Package for the Social Science (SPSS), version 19 was used for statistical treatment of the data, applying descriptive statistics through central trend measures. Gender differences were determined with the help of non-parametric statistics, using the chi-square test to verify the relation between nominal variables. ${ }^{7}$ Pearson's parametric $\mathrm{R}$ correlation test was also used to measure the intensity of the relation between quantitative variables that showed a normal distribution. This linear association measure can range between -1 and 1 , establishing that $\mathrm{R}$ inferior to 0.2 means a very low linear association; between 0.2 and 0.39 low; between 0.4 and 0.69 moderate; between 0.7 and 0.89 high; and between 0.9 and 1 very high. A negative $R$ indicates a negative linear relation. ${ }^{8}$ All tests were considered statistically significant at $\mathrm{p}<0.05$.

\section{RESULTS}

As regards the interviewed elderly hypertension patients' sociodemographic characteristics, $62.4 \%$ were female and $37.6 \%$ male. Most of them lived with their partner (66\%) and came from rural $(63.6 \%)$ and urban areas (36.4\%). Moreover, $58.8 \%$ of the elderly were between 65 and 75 years of age and 93.2\% lived in their own home. Also, all respondents were retired and $58.5 \%$ came from medium-low socioeconomic classes (low socioeconomic level and low education level). All participants took one or two anti-hypertensive drugs and $96.4 \%$ answered the question about adherence to pharmacological treatment of the SAH affirmatively (MTA scale). The elderly patients' mean age was 74 years, the BMI was 29 $\left(\mathrm{Kg} / \mathrm{m}^{2}\right)$ and the mean systolic and diastolic BP levels (mmHg) corresponded to 145.5 and 74.4, respectively, as observed in table 1. 
Table 1 - Anthropometric characteristics, BP and total cholesterol. Chaves-Portugal, 2011

\begin{tabular}{lcccc}
\hline Variable & Minimum & Maximum & Mean & Standard deviation \\
\hline Age $($ years $)$ & 65 & 95 & 74 & 6.00 \\
Body weight $(\mathrm{Kg})$ & 44 & 118 & 71.80 & 13.90 \\
Height $(\mathrm{m})$ & 1.28 & 1.84 & 1.57 & 0.08 \\
BMI $\left(\mathrm{Kg} / \mathrm{m}^{2}\right)$ & 19 & 47 & $\mathbf{2 9}$ & 4.60 \\
Systolic BP $(\mathrm{mmHg})$ & 90 & 225 & $\mathbf{1 4 5 . 5 0}$ & 19.20 \\
Diastolic BP $(\mathrm{mmHg})$ & 40 & 119 & 74.40 & 12.30 \\
Total cholesterol $(\mathrm{mg} / \mathrm{dl})$ & 106 & 332 & $\mathbf{2 0 1}$ & 39.20 \\
\hline
\end{tabular}

Systolic BP was superior to $140 \mathrm{mmHg}$ in observed in figures 1 and 2, most cases refer to iso$69.6 \%$ of the interviewed elderly, while diastolic lated systolic arterial hypertension, characteristic BP levels were inferior to $90 \mathrm{mmHg}$ in $88.4 \%$. As of systemic arterial hypertension in elderly people.

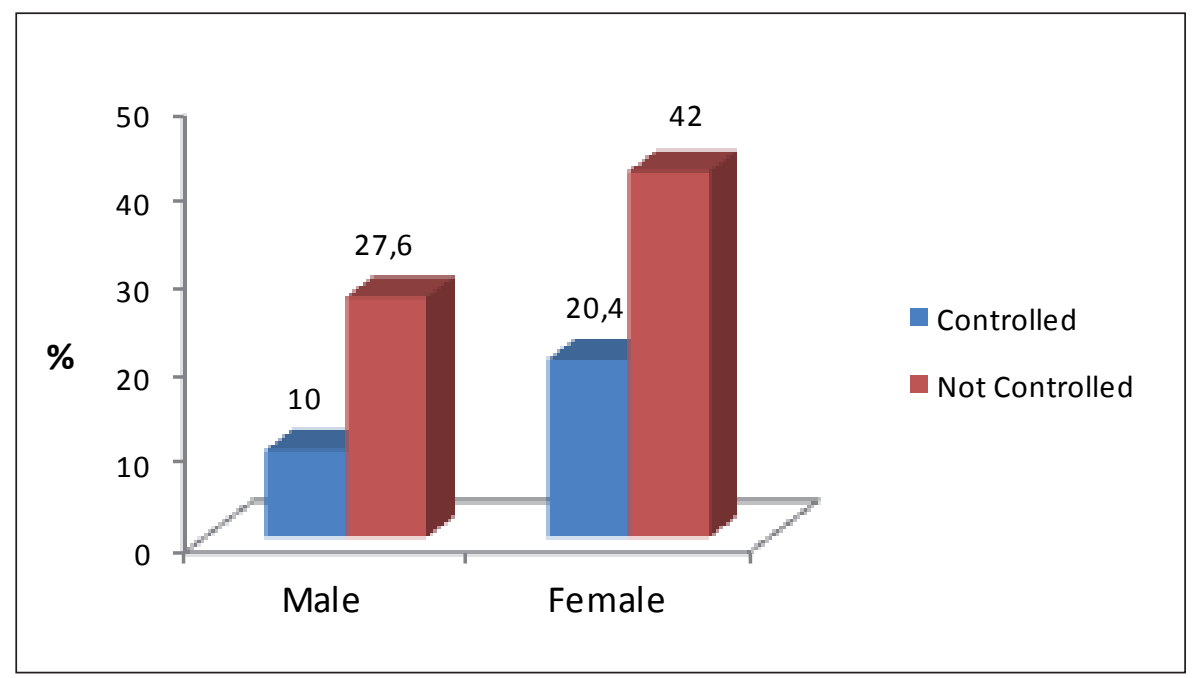

Figure 1 - Systolic blood pressure according to gender. Chaves-Portugal, 2011

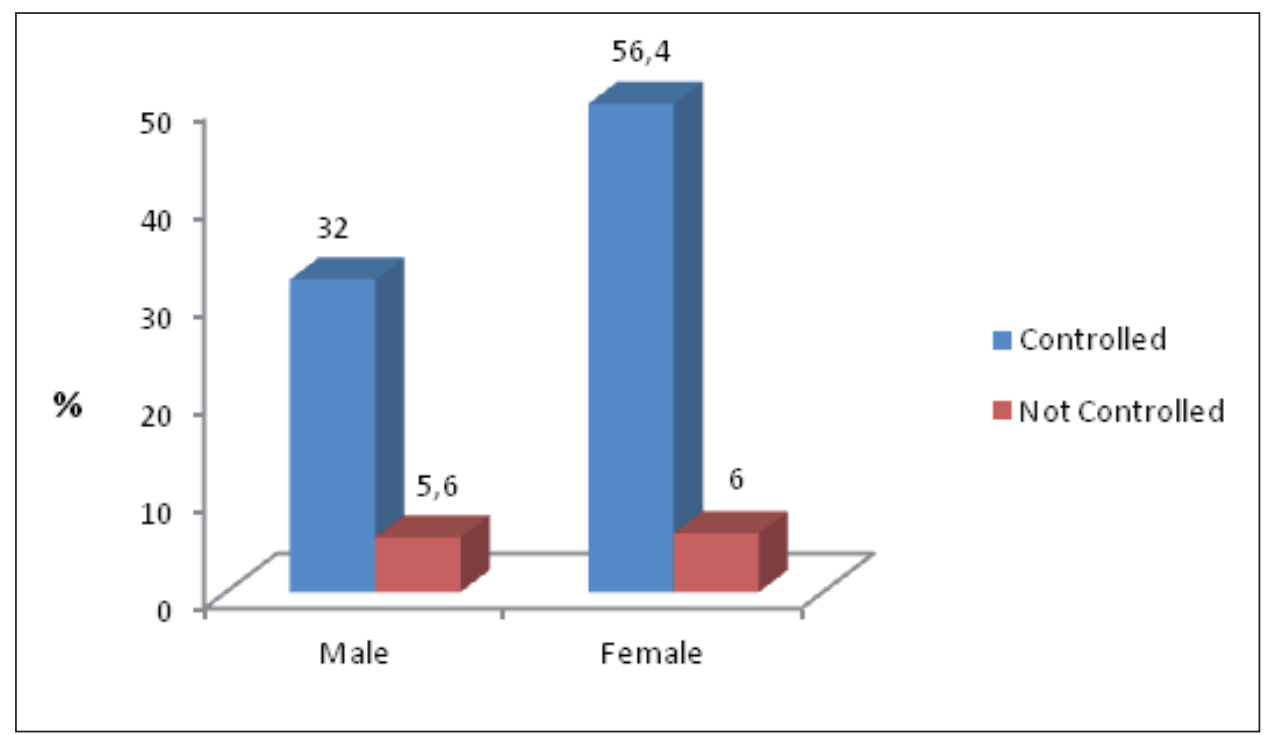

Figure 2 - Diastolic blood pressure according to gender. Chaves-Portugal, 2011 
No statistically significant relations were found between systolic BP and gender $\left(X^{2}=1.030\right.$; $p=0.192)$ and between diastolic BP and gender $\left(X^{2}=1.594 ; p=0.145\right)$, evidencing the enhanced prevalence of isolated systolic hypertension in male and female elderly.
As regards the participants' BMI according to gender, overweight and obesity were present in $43.6 \%$ and $39.6 \%$ of the elderly, respectively, with high indices in both genders, as observed in Table 2, underlining sic cases of morbid obesity $\left(\mathrm{BMI} \geq 40 \mathrm{Kg} / \mathrm{m}^{2}\right)$.

Table 2 - Body Mass Index (BMI - Kg/m²) and gender. Chaves-Portugal, 2011

\begin{tabular}{lccc}
\hline Nutritional status & Male (\%) & Female (\%) & Total (\%) \\
\hline Underweight & - & - & - \\
Normal weight & $11(11.7)$ & $25(16.0)$ & $36(14.4)$ \\
Overweight & $39(41.5)$ & $70(44.9)$ & $109(43.6)$ \\
Obesity & $40(42.5)$ & $59(37.8)$ & $99(39.6)$ \\
Morbid obesity & $4(4.3)$ & $2(1.3)$ & $6(2.4)$ \\
Total & $\mathbf{9 4 ( 1 0 0 )}$ & $\mathbf{1 5 6 ( 1 0 0 )}$ & $\mathbf{2 5 0}(\mathbf{1 0 0})$ \\
\hline
\end{tabular}

Also, a positive but not significant correlation (Pearson's R) can be observed between systolic BP and BMI $(R=0.084 ; \mathrm{p}=0.185)$; systolic $\mathrm{BP}$ and Total cholesterol $(R=0.028 ; \mathrm{p}=0.662)$, and systolic BP and Body weight $(R=0.049 ; \mathrm{p}=0.442)$, respectively.

Regarding eating habits, although no strict dietary pattern could be established among the participants, less appropriate and hardly healthy diets were found, with excessive salt and saturated fat intake. Among the 250 elderly assessed, 71.2\% do not usually have a snack after dinner (tea or low-fat milk, or cookies) and $40.4 \%$ do not have a snack between lunch and dinner, evidencing that most participants have three meals: breakfast, lunch and dinner.

As regards physical exercise, $54.8 \%$ of the elderly do not practice any type of exercise regularly. Among the reasons, physical limitations (28\%) like bone-joint pain; exercise as a part of daily activities $(20 \%)$ and loss of motivation $(6.8 \%)$ are highlighted, suggesting that regular and moderate physical exercise are not part of most of these elderly patients' daily routine.

\section{DISCUSSION}

SAH control in elderly patients is difficult, even when anti-hypertensive drugs are prescribed. These results emphasize the evidence that the most frequent type of hypertension in people aged 65 years or older is isolated systolic arterial hypertension (systolic BP>140 $\mathrm{mmHg}$ and diastolic $\mathrm{BP}<90 \mathrm{mmHg}$ ) which, according to the authors, increased the risk of an acute stroke, left ventricle hypertrophy and cerebrovascular accident by two to four times. ${ }^{9}$

Advanced aged, low socioeconomic level and low education are indicated as important factors that negatively influence SAH in elderly patients. Social and economic differences play an important role in health conditions, as they originate other factors, such as the degree of information, access to health services, understanding about the health and disease situation and the management of the therapeutic regimen, considering not only pharmacological, but also non-pharmacological treatment. ${ }^{10}$

Another study on arterial hypertension in elderly women indicates concerning results regarding obesity $(40.5 \%)$, as its association with other non-transmissible chronic conditions causes increased morbidity and mortality levels, and also affects the health system and reduces the elderly patients' quality of life. ${ }^{11}$

Identical results have been obtained in other studies, granting knowledge about these clients' characteristics and about risk factors for cardiovascular diseases, which has been important to plan high-quality care delivery to elderly patients with SAH. ${ }^{12}$

The prevalence of obesity is higher in poorer social classes. ${ }^{13}$ Other studies evidence this, underlining that overweight and obesity are directly related with a positive energy balance, resulting from a higher intake in comparison with the amount of calories spent. Another studies about elderly patients and SAH also found a predominance of 
patients with high levels of overweight and obesity $(80 \%)$ and a mean BMI of $29.12 \mathrm{Kg} / \mathrm{m}^{2}{ }^{14}$

Another relevant piece of information regarding high $\mathrm{BMI}$ and $\mathrm{SAH}$ is the presence of high total cholesterol levels. Data from the Fundação Portuguesa de Cardiologia about the Portuguese population's lipid profile indicate that a considerable part of that population $(68.5 \%)$ is at a moderate risk of cardiovascular illness (total cholesterol $>190 \mathrm{mg} / \mathrm{dl}$ ), while about $23.4 \%$ are at high risk (total cholesterol $\geq 240 \mathrm{mg} / \mathrm{dl}$ ). ${ }^{14}$

The metabolic syndrome evidences the role of fat cells at the waist level. Its definition is based on the presence of at least three of the following criteria: obesity (BMI $\left.>30 \mathrm{Kg} / \mathrm{m}^{2}\right)$; waist perimeter $(>102 \mathrm{~cm}$ in men and $>88 \mathrm{~cm}$ in women); arterial hypertension ( $>130 / 85 \mathrm{~mm} \mathrm{Hg}$ ); high triglycerides levels (>150 mg/dl); HDL cholesterol (<40 mg/dl in men and $<50 \mathrm{mg} / \mathrm{dl}$ in women); and normal or slightly higher LDL and glucose levels (>110 mg/ dl). ${ }^{5}$ The metabolic syndrome is a precursor of diabetes and cardiovascular diseases, with obesity and the abdominal perimeter as important factors. ${ }^{5,15-16}$ Other factors predisposing to overweight and obesity in the elderly are the reduction of energy needs caused by reduced lean body mass and a sedentary lifestyle. Chronic physical disabilities, present in the elderly, can also reduce activity and increase BMI levels even further.

Epidemiological studies have demonstrated that obesity is the main predisposing cause of hypertension and type II Diabetes Mellitus. These indicate that, in the treatment of obese elderly patients with hypertension and/or diabetes, weight reduction is the first step, which health professionals should strongly emphasize. ${ }^{5,17}$

Healthy, appropriate and balanced eating habits are fundamental to maintain one's body weight and good nutritional status. Reducing saturated fat intake, involving red meat, fat cheese, butter, sweet and sugared foods, limiting salt and alcohol consumption and increasing the intake of fresh vegetables, fruits and fish contribute to reduce obesity, normalize BP levels and reduce other comorbidities, such as type II Diabetes Mellitus, cardiovascular diseases and cancer. Body weight reduction in overweight or obese and $\mathrm{SAH}$ patients does not only benefit blood pressure levels, but also enhances the effect of anti-hypertensive drugs, significantly reducing other associated cardiovascular risk factors. ${ }^{18}$
Activity and regular and moderate physical exercise are equally essential for SAH and obesity treatment and are fundamental in daily life. They balance excess calorie consumption, lower cholesterol levels, improve blood glucose levels and promote relaxation and the reduction of stress levels, an equally significant factor in this problem. ${ }^{19-20}$

Obesity represents an important public health problem in Portugal, demanding strategies that consider the promotion of healthy living habits and an active life. The planning of preventive measures and their implementation should be a priority for health care services.

The reduction of sedentariness and regular physical exercise have illustrated the positive influence on elderly quality of life, favorably affecting the struggle against obesity, the reduction of triglyceride and total cholesterol levels in the blood, the increase of high-density lipoprotein (HDL) and the improvement of BP levels.

\section{CONCLUSIONS}

Given the range and complexity of this public health problem, i.e.SAH, among elderly people in Portugal, it is important for health professionals, including nurses, to develop intervention strategies on behalf of aging populations, improving measures to control BP and other cardiovascular risk factors, such as body weight and sedentariness. In this research, evidence was produced that various risk factors associated with SAH contribute to the complexity of elderly people's clinical and health situation, hampering the control of blood pressure levels. Physical exercise and healthy eating habits should be perceived as fundamental non-pharmacological therapeutics in SAH, which add up to anti-hypertensive medication.

In view of this reality, it is essential for nursing actions involving hypertensive elderly people to include strategies aimed at promoting healthy lifestyles and encouragement, interacting with personal accountability in training to further selfcare and a better quality of life.

\section{REFERENCES}

1. Carmo I, Santos O, Camolas J, Vieira J. Obesidade em Portugal e no mundo. Lisboa (PT): Faculdade de Medicina da Universidade de Lisboa; 2008.

2. Azeredo Z. O idoso com um todo. Viseu (PT): Psico \& Soma; 2011. 
3. Mancini MC. Obesidade e doenças associadas. In: Mancini MC, Gelonze B, Salles JEN, Lima JG, Garra MK. Tratado de obesidade. Itapevi (SP): AC Farmacêutica; 2010.

4. Faulhaber H. A hipertensão. Lisboa (PT): Editorial Presença; 2008.

5. Brack M. La hipertensión arterial. Barcelona (ES): Editorial Hispano Europea; 2009.

6. Caetano JA, Costa AC, Santos ZMSA, Soares E. Descrição dos fatores de risco para alterações cardiovasculares em um grupo de idosos. Texto Contexto Enferm. 2008 Abr-Jun; 17(2):327-35.

7. Pereira A. Guia prático de utilização do SPSS: análise de dados para ciências sociais e psicologia. Lisboa (PT): Edições Sílabo; 2008.

8. Pestana M, Gageiro J. Análise de dados para ciências sociais: a complementaridade do SPSS. Lisboa (PT): Edições Sílabo; 2008.

9. Pádua F. O livro do coração: viver mais e melhor. Alfragide (PT): Academia do Livro; 2008.

10. Kümpel DA, Sodré A, Pomatti DM, Scortegagna HM, Filippi J, Portella MR, et al. Obesidade em idosos acompanhados pela Estratégia de Saúde da Família. Texto Contexto Enferm. 2011 Jul-Set; 20(3):471-7.

11. Oliveira SMJV, Santos JLF, Lebrão ML, Duarte YAO, Pierin ÂMG. Hipertensão arterial referida em mulheres idosas: prevalência e fatores associados. Texto Contexto Enferm. 2008 Abr-Jun; 17(2):241-9.

12. Martins L, Guedes N, Teixeira I, Lopes M, Araújo T. Nível de actividade física em portadores de hipertensão arterial. Rev Latino-Am Enfermagem [online].2009 [acesso 2012 Ago 10]; 17 (4). Disponível em:http:/ / www.scielo.br/scielo.php?pid=S0104$11692009000400005 \&$ script $=$ sci_arttext\&tlng $=$ pt

13. Carmo I. Estudos epidemiológicos dos fatores de risco de doenças cardiovasculares e diabetes. In: Carmo I, Santos O, Camolas J, Vieira J. Obesidade em Portugal e no mundo. Lisboa (PT): Faculdade de Medicina da Universidade de Lisboa; 2008.

14. Gami AS, Witt BJ, Howard DE, Erwin PJ, Gami LA, Somers VK. Metabolic syndrome and risk of incident cardiovascular events and death: a systematic review and meta-analysis of longitudinal studies. J Am Coll Cardiol. 2007 Jan; 49(4):403-14.

15. Santos JC, Moreira TMM. Fatores de risco e complicações em hipertensos/diabéticos de uma regional sanitária do nordeste brasileiro. Rev Esc Enferm USP [online]. 2012Out [acesso 2012 Dez 28]; 46(5):1125-32. Disponível em: http:/ / www.scielo.br/ scielo.php?pid=S008062342012000500013\&script=sci_arttext

16. Miranzi SSC, Ferreira FS, Iwamoto HH, P GA, Miranzi MAS. Qualidade de vida de indivíduos com Diabetes Mellitus e hipertensão acompanhados por uma equipe de saúde da família. Texto Contexto Enferm. 2008 Out-Dez; 17(4):672-9.

17. World Health Organization. European action plan for food and nutrition policy 2007-2012. Copenhagen (DK): WHO Regional Office for Europe. Scherfigsvej $8 ; 2008$.

18. Mendes RMN, Lourenço CAM. Actividade física no doente hipertenso. Rev Nursing. 2008 Jan; 229: 6-12.

19. Mendes R, Barata JLT. Exercício aeróbio e pressão arterial no idoso. Rev Port Clin Geral. 2008; 24: 251-7. 